\title{
At the Mountains of Monstrosity Towards Ecomonstrous Entanglements through Images of a Fjord
}

\section{By Daniel Otto Jack Petersen}

\begin{abstract}
Twenty-first century developments in ecophilosophy argue for a growing awareness that nonhumans ('organic' or otherwise) possess both vibrant agency and dark interiority and, therefore, humans - even environmentally conscious ones - must relinquish their presumed centrality and apartness from other things (anthropocentrism). Standard motivations for environmental responsibility, such as appeals to the crisis of human-caused global warming, are here postponed in order to seek means of allowing nonhuman agency and interiority to 'speak' or make itself felt. The article claims mountains themselves initiated this human-nonhuman entanglement and tries to follow their lead into reconfigured (non-anthropocentric) visions of coexistence. Its many-appendaged ecopoetics is comprised of photographs and recollections of mountains stitched together with the conceptual tools of monster theory, object-oriented ontology, and vital materialism. Viewed through this theoretical nexus, a hole in a photograph of the Lysefjord provokes the suggestion that holes in ontology are perforations through which human being seeps into nonhuman being and is therein transfigured, emerging porous and suffused, as much 'the environment' as anything else. The article's necessary provisionality means further engagement - especially from other 'witnesses' of mountains - is required to test its effectiveness as an aestheticcontemplative preface to deeper, wiser ecological ethics.
\end{abstract}

\section{KEYWORDS}

Mountains, monsters, ecocriticism, ontology, nonbumans, coexistence

Daniel Otto Jack Petersen is a PhD candidate at University of Glasgow. His research areas include ecocriticism, monster studies, and object-oriented ontology. 


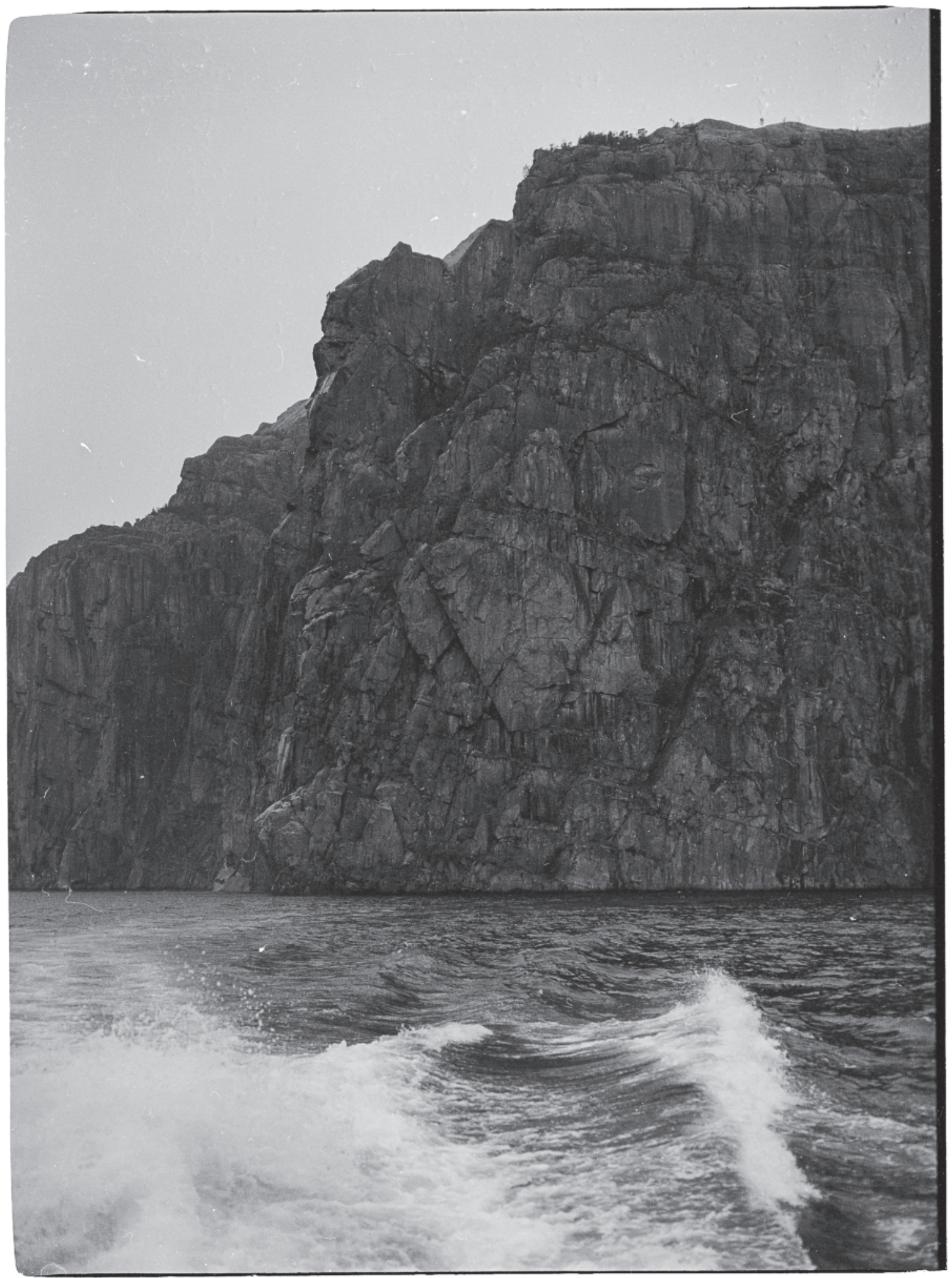




\section{Moved by Mountains}

The mountains lining the Lysefjord provoke this meditation. We briefly visited this landscape during the 2016 Promises of Monsters conference in Stavanger, Norway. (The 'we' here being myself and my wife, the fine art photographer Andrea Petersen, aka Flannery O'kafka). ${ }^{1}$ Seeing the mountains that rose on either side of the fjord, I was struck with how this Nordic geomorphology strangely echoes that of the mountain ranges of Scotland, where we reside. The mountains of the fjord resonate perhaps especially with the Scottish mainland ranges of Glencoe and the Cairngorms and with the Black Cuillin on the Isle of Skye. It is not so much that the Scottish and Norwegian ranges have similar reliefs, but that both give a distinct sense of the monstrous and of movement. When I, originally a flatlander from the Midwestern USA, first encountered the mountains of the Scottish Highlands two decades ago, I was overwhelmed with a sense of gigantic monstrous bodies: massifs like prehistoric sea beasts and peaks like primordial giants, the rippled and green-furred surfaces of which might shift any moment to reveal some gargantuan monstrous face with eyes like glowing caverns, gazing into which would be the end of sanity.

Such gigantesque anthropomorphism is not unheard of in relation to mountains. ${ }^{2} \mathrm{~A}$ famous triplet of ridges in the Bidean nam Bian mountain near Glencoe is called The Three Sisters. I've driven the road that passes them a number of times and I can tell you that these are three fearsome siblings! A striking instance is also found in a little book called The Living Mountain by Nan Shepherd of Aberdeen, Scotland. It's an account of her lifelong personal experiences of walking in the Cairngorms (written in the 1940s but not published until the 1970s). She wrote of the mountain, Ben MacDhui, that he "towers up like the giant he is" and that the "lump-mass, rounded and unshapely," of that moun- tain's backside is "like the back of a monster's head: at the other side are the open jaws, the teeth, the terrible fangs" (Shepherd 2011, 20). This impression of vast and living monstrosity persists across a century and no doubt reaches back through many more. ${ }^{3}$

That initial feeling has never really left me. In the Lysefjord, I was struck with something of a corresponding sense that the mountains towering over us on our fjord cruise were the magnificent, cyclopean heads of Lovecraftian Old Ones rearing up with aching slowness out of this enormous glacial scar in the earth. I felt as if these beings had only recently broken the water's surface and the rest of their eldritch bulk was still hidden in the murky depths below. We were tiny humans touring amidst a host of titans - lithic giants whose hoary brows evoked the humanoid, the bestial, and the celestial in cephalomantic amalgamation. We quailed (yet exulted!) before the risen visages of these earth deities both Cthulhu-esque and troll-like. Norwegians have clearly also felt such monstrous associations elsewhere in their native geomorphology as evidenced by toponyms such as Trollveggen (Troll Wall) and Jotunheimen (Home of the Giants). In the midst of that fjord a strange desire for communion with those uncanny mountains came over me, a desire to know them and, in some unarticulated sense, to be known by them - in nonhuman-human entanglement. Thus began the germ of this article.

\section{With THE MOUnTaIns of Monstrosity}

The title of this article alludes to H.P. Lovecraft's celebrated novella At the Mountains of Madness (1936). The metaphysical orography we will pursue here, however, isn't so much about arriving 'at' these mountains. 4 That preposition's connotations of mere arrival and proximation could suggest a zoo-like viewing through a glass 
barrier of human exceptionalism. Our approach is, rather, an attempt to be with the mountains, learning to recognise our deep coexistence by rewiring our thinking and feeling away from anthropocentrism toward something harder to name. We want to glimpse the human becoming folded into the mountain's ontology through metaphoric guesswork (cf. Bogost 2012). ${ }^{5}$

This guesswork methodology is suggested to us by Ian Bogost's concept of 'metaphorism', in which one sympathetically follows the evidence of what an object presents to her and then imaginatively, poetically 'guesses' her way into some fleeting image of its subjective life as that object per se (Bogost 2012, 61 ff.). Ontological metaphorism does different work than that of the scientist defining physical properties and causal relations. Given that it starts from an account of objects as withdrawing and inexhaustible (see the section on object-oriented ontology below), it is intentionally, and perpetually, provisional. It is also self-consciously weird and strange, especially epistemologically, requiring us to expand, and sometimes break, our habits of knowing (Bogost 2012).

In this article's attempt to practice something approaching metaphorism, we find ourselves yawing between creatively receiving from the mountains (by experience, by impression, by account, by geography and geology, by artistic representation, by any means available to us) and creatively responding to the mountains in the hesitant construction of collaborative, ongoing, human-nonhuman visions of their ontology based on what they continually give to us from the dark plenum of their existence. If this article exhibits a tendency to fall short of describing, even tentatively, 'what it's like to be a mountain', and instead falters into weirder interstices (the 'hole' being its central metaphor), we might consider such ontological clumsiness a backhanded virtue. An authentically deanthropocentrising project, after all, must needs proceed with demonstrable humility, provisionality, and strangeness. Indeed, despite our emphasis on being with the mountains - or 'becoming-with' and 'making-with' them (Haraway 2016) - I have retained the 'At' in my allusive title to remind us that crossing over from mere ecotourism into the stranger territory of sustained ecological thinking requires effort and time (and probably false moves and retracing of steps). Visiting and viewing scenes and sites isn't enough.

The case at hand is complicated further in that my wife and I were in Stavanger for only a very short time and we don't know when we might return to Norway. Thus, in lieu of further physically exploring those mountains at this time, I here suggest paths of imaginative preparation through insights and intimations from monster theory, object-oriented ontology (OOO), and fine art photography, which help me cultivate a disposition of strange empathy toward mountains. Perhaps it can also be cultivated in those who do physically journey or dwell among mountains and in those who study their physical and cultural history or current political status. It is hoped that the inevitably universal feel of the theoretical discussion that follows will bear fruit in material particularities.

I have tried in a few places, at least, to salt the theory-speak with actual experiences of Scottish mountains (my own and those of Nan Shepherd), which I hope suggest translations into Norwegian contexts. A transgeographical rapport between diverse mountain ranges and their various human sympathisers seems desirable to me - for its own sake, as argued below, but also to increase our sense of weird global 'tentacularity', Donna Haraway's term for the lines and nets and relays of 'sympoietic', multi-species storytelling and worldbuilding (cf. Haraway 2016, 32-33). And this is achieved, I submit, by the heightening, rather than diminishing, of local regional specificity in our ecological poetics.

In this article, we unfurl tentative tenta- 
cles across the oily North Sea, snaking appendages that writhe between images of Norwegian mountains and experiences of Scottish mountains (among other things). Perhaps thinkers-with-mountains in Nordic contexts will echo this experiment back to us, refracting, correcting, and constructing other stories, further images, a blooming of mountainous feelers coiling back and forth across the regions.

\section{WARning: This ARTICLE IS UsELEsS}

Of course, it might be asked: why cultivate empathy with mountains? Why think and live ecologically at all? In a certain sense, to give a justification for this project would be to betray it. To ask what 'use' there is for humans in (re)awakening ourselves to the strangeness of ecology and our strange place of enmeshment within it is to veer back toward anthropocentrism before we've begun our journey away from it. To think 'the ecological thought', to use Timothy Morton's phrase, is to re/cognise the eerie scope and scale and weird entanglements of ecological coexistence (cf. Morton 2010, 30-33). True, ignorance and abuse of these vast and intricate entanglements has resulted in such effects as anthropogenic climate change - i.e. global warming produced by the epoch of the Anthropocene, the age of the discernibility of humanity's giant geological footprint (cf. Morton 2016, 7-9). But first and foremost, the strange entanglements just are, ecological coexistence just is. To become aware of this is - so the ecological thought goes - to be in better touch with reality (even if this touch is only the tingling, uncanny brush of existence on existence rather than the firm and frank handshake of a crisp reductionist business deal).

Ethical and political actions will certainly follow from the ecological thought, but first it must be thought! Indeed, the very act of thinking is characterised by Hannah Arendt as “training one's mind to going visiting" (cited in Haraway 2016, 177). It is precisely this 'going visiting' with mountains that this meditation must busy itself with (in a sense beyond merely a visit to a 'scene' or landscape as noted above). To ask for the justification of such visiting seems rather to miss the point. Our mountainous neighbours may be "strange strangers" (Morton 2011, 165), but that's no excuse for failing to be neighbourly when they call (however uncanny the call) or for requiring that the visit be of some use to us beyond the encounter itself. "A thing impinges on me before I can contain it or use it or think it. This impingement is not susceptible to being pinned down" (Morton $2016,150)$. Not even pinned down by our very real need to engage with urgent planetary issues.

More radical still, in honour of thingly impingement, this article attempts to give some priority to the nonhuman in our awakening to ecological entanglement. I allege that a colossal inhuman entity gently rocked my tiny shoulder, as it were, and roused me from my anthropocentric slumber (to riff on Kant's famous statement about his reading of Hume's scepticism). In a sense, I am claiming that the mountains spoke to me first and here, in part, I am speaking back in my odd little human way. Casting ourselves in the role of responder, as tiny sleeper and second speaker, nudges us toward a decentring of the human. And so, folds us a little deeper into ecological thinking and living; that is, into an ethos and praxis that accords with the depth and breadth of fragile coexistence on this planet.

If one can grasp the point that the ecological thought is, at least initially, 'useless', then one has already begun to actually think it. One is slipping through the cracks of anthropocentrism. As Jane Bennett points out, it is often the case that as soon as nonhumans really make an appearance in public awareness (stem cells, trash, weather, food, electricity), they are swiftly absorbed into human agendas and affections. "This 


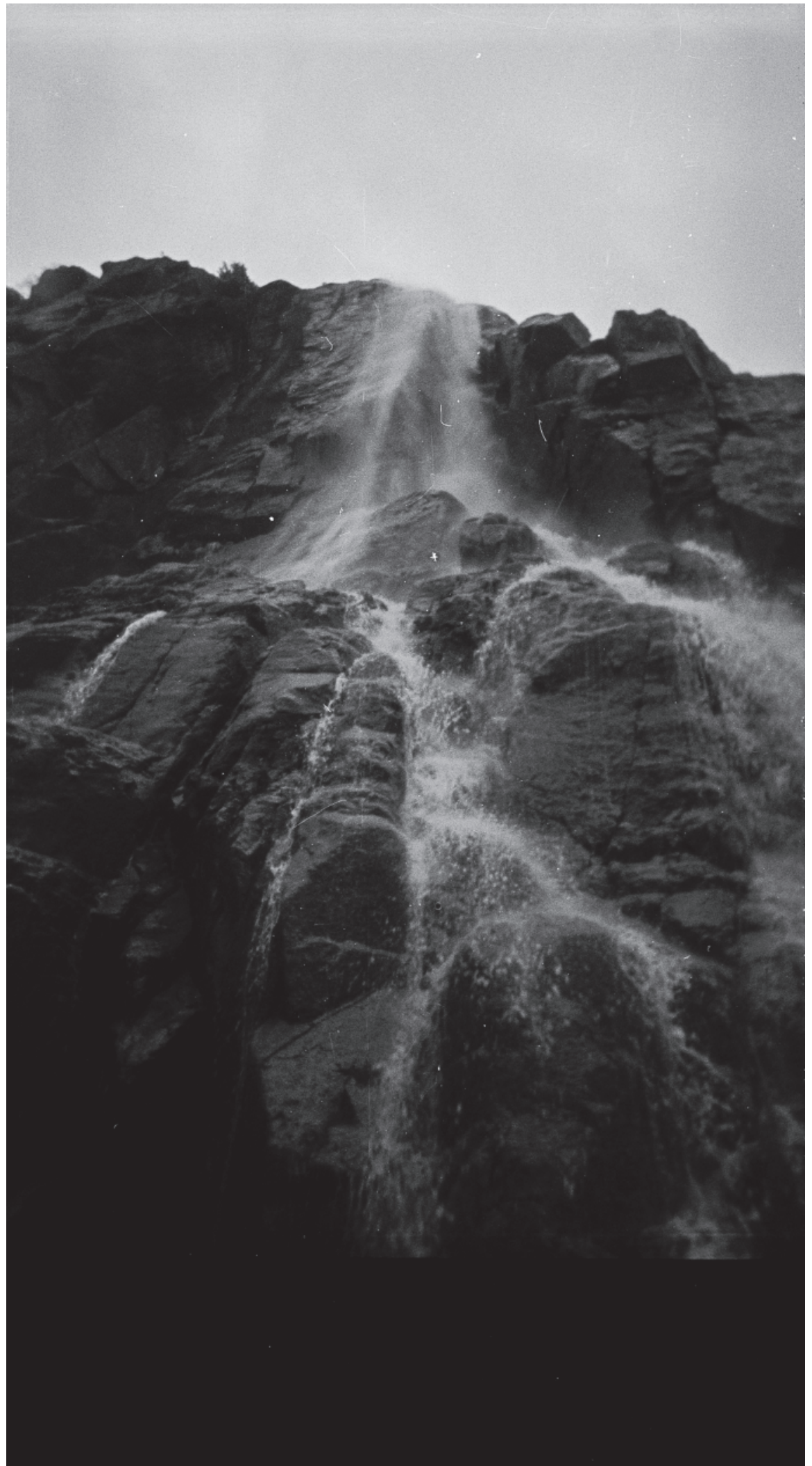


quick substitution sustains the fantasy that 'we' really are in charge of all those 'its"' (Bennett 2010, x; cf. Morton 2016, 26). You have been warned: this is article is useless for sustaining that fantasy.

\section{More Than Monsters OF THE Mind}

Monsters are real. Let's begin with that claim. Quite apart from subjective human impressions of mountain morphology as monstrous, mountains simply possess qualities of the monster. In the unwitnessably slow undulations of their upthrusts and erosions, and in the ecosystemic mantles of flora, fauna, and weather that they wear (a living texture that includes humans in its weave), mountains exemplify Jeffrey Cohen's widely influential characterisation of the monster as a "harbinger of category crisis" (Cohen 1996, 7). The monstrous body, for example, consists of a "freakish compilation" of incompatible parts (ibid.). How does a mountain present such a monstrous body?

Briefly, we might note that some geographers and philosophers hold that, despite our commonsense intuitions to the contrary, "mountains do not exist in quite the same sense as do such prototypical everyday objects as chairs or people, crows or cups" (Smith and Mark 2003, 411). These everyday objects are considered instances of what philosophers call 'natural kinds' (ibid.). Mountains, on the other hand, "do not have determinate, prominent, and complete boundaries", which are said to be requisite for being designated an object of a natural kind (ibid., 412). Instead, it is argued, the ontology of mountains is "to be located at the interface between the behavior of organisms, on the one hand, and the large-scale environment, on the other" (ibid., 415). Mountains are thus "objects whose boundaries are marked by gradedness or vagueness" (ibid., 422), shimmering at the border between the behaviours of living things and the landforms that influence those behaviours. Whether we throw in with the philosophers here or not, their categorial wranglings demonstrate that mountain being is strange, hybrid, ghostly (cf. Della Dora 2016).6 The mountain transgresses our binaries of life/nonlife, animate/inanimate, especially if we are willing to call it, with Nan Shepherd, a 'living mountain' (cf. Bennett 2010).

Mountains are monstrous in their blurring of movement and non-movement as well. Their abiding presence and natural history provoke us to simultaneously perceive mountains as monuments of changeless stability as well as eerie clocks of inhuman scale that tick off the depths of geological time. After all, the rise and fall of mountains amounts merely to effervescent gooseflesh on the Earth's shifting crust as the planet is touched by the chill breeze of cosmic time. ${ }^{7}$ The inhuman rhythm of this tectonic tempo stirs our bones to follow the mountain's eerie, decentring dance.

Its injunction is always to step out of the breathless rapidity of anthropocentric frames and touch a world possessed of long futurity and deep past, a spatial expanse that stretches from the subterranean to the cosmic verge.

(Cohen 2015, 33)

In neither being entirely one thing or another, mountain being evinces monstrous “ontological liminality" (Cohen 1996, 6). Granted, only human language calls this shifting multiplicity 'monster', yet the liminal qualities of the mountain precede human perception and call out to languageusers to give it a name suitable to its strange nature. The mountain is a harbinger of category crisis for humans not only in their minds, but because it actually exists, fully and solidly, in a ghostly manner that freakishly fuses types of being and form elements and animals, the lithic and the vegetal - and polarised senses of speed, stability, space, and time. 


\section{OOM}

The school of thought known as objectoriented ontology (OOO) shows promise for acknowledging and accommodating this very real strangeness about very real things. OOO's central contention is that "things have an irreducible dark side" (Morton 2011, 165). That is, "things exist in a profoundly 'withdrawn' way: they cannot be splayed open and totally grasped by anything whatsoever, including themselves" (Morton 2016, 16). This means that every object of every kind recedes from all its 'uses' and interconnections into the ontic darkness of its inaccessible and inexhaustible interiority. ${ }^{8} \mathrm{~A}$ mountain, in this view, would not be reducible to any presenting feature or function we may recognise in it, nor the bond that obtains between it and any weather, fauna, flora, or other landform (even when, as is the case with a liminal being like the mountain, it is in part comprised of these very things, cf. Smith and Mark 2003, 412; Price 2015, 43-44).

For OOO, no other thing will ever exhaust the replete darkness of the mountain's being (just as the mountain will never exhaust the being of anything it draws into its orbit). Yet this withdrawnness also supplies a bottomless capacity for the mountain to surprise us with new, and not necessarily cohesive (in keeping with its monstrosity), manifestations of itself (cf. Harman 2012, 165-166). It thus exhibits itself to be what Morton calls a 'strange stranger':

Strange stranger names an uncanny, radically unpredictable quality of life-forms. Life-forms recede into strangeness the more we think about them, and whenever they encounter one another - the strangeness is irreducible. Ecological philosophy that does not attend to this strangeness is not thinking coexistence deeply enough. (Morton 2011, 165)

Attending to the strangeness of coexistence (inclusive of non-lifeforms as well, such as rocks or wind or oil, which Morton acknowledges elsewhere) is precisely our project here.

Ascribing this dark, withdrawn quality to objects of the world has the virtue of drawing centrality away from the human, creating instead a spiralling, fractal sort of vision of coexistence, an uncanny, looping 'weird weirdness' (Morton 2016, 6 ff.). This view is not merely ecocentric but, as we might say, 'eco-eccentric', where every object draws the world into itself, claiming full integrity even as it intertwines with all else. This vision affects our concept of the monstrous as well. Cohen's cultural account of monstrosity contends that monsters really do exist in that they arise from within the human psyche and return to us in the form of cultural manifestations that interrogate our assumptions and prejudices toward (sexual, racial, economic) difference (Cohen 1996).

In keeping with OOO's emphasis on dark interiority in all things, I want to suggest also a less anthropocentric and more object-oriented monstrosity (OOM) that acknowledges the extrinsic existence of monsters lurking in the hidden depths and across the writhing surfaces of what we tend to call the environment. That is, the uncanny border impurities of monsters arise not only from our minds but from the actual ontology of nonhumans, whether we perceive them as such or not. OOM would suggest that environmental monsters project themselves onto us as much as we project our perception of the monstrous onto the environment. Their alterity and liminality press in on us and demand to be encountered, even cherished. ${ }^{9}$

\section{Black Hole in the Mountain}

How might we make ourselves more darkly attuned to the monstrous mountains then? One way is to discover "a technique for contacting the strange stranger" (Morton 2011, 167). My wife and I can both attest 
that the mountains reached out and made first contact with us. From our first experience of Scottish mountains in the Highlands (in the summer of 1999) we found ourselves ensorcelled, even pierced, by mountain beauty and being. Indeed, the mountain is a landform most humans simply cannot take for granted as mere 'environment'. ${ }^{10}$ Yet, as noted above, the mountain's being also withdraws. It's almost as if, having tagged us with the frisson of $\mathrm{co}^{-}$ existence, the mountain invites us to chase after its perpetual retreat into darkness.

There will be no easy access, however, for mountains, like all objects, are terrestrial aliens. Unlike the ever elusive extraterrestrial, this earthly alien "is not hidden in the darkness of the outer cosmos or in the deep-sea shelf but in plain sight, everywhere, in everything" (Bogost 2012, 34). Yet even given their terran proximity, we must engage the mountains as we would an encounter between intergalactic species, where "we never understand the alien experience, we only ever reach for it metaphorically" (ibid., 66).

In response to the mountain's uncanny touch, then, we want to tentatively pursue and welcome "intimacy with an alien presence" wherever we can find it (Morton 2011,171 ). While there may be many possible ways to cultivate xenophilic encounters with mountains - including, of course, physically traversing them - we will here pursue "affective-contemplative techniques for summoning the alien", strategies both aesthetic and discursive for "lifting us out of anthropocentrism” (ibid.).

Talk of black holes is one way to conceptualise the dark interior of objects posited by OOO (Bogost 2012). By attending to each object's unique "logic and sense making", its singular reality is traced "just as the radiation around an event horizon helps an astronomer deduce the nature of a black hole" (ibid., 28-29). We require, however, something weirder than the deductions of an astronomer. If the moun- tains are ontologically withdrawn, then "one must proceed like the carnival barker rather than the scholar: through educated guesswork" (ibid.).

We tumble into our carnivalesque guesswork, then, through a hole in a photograph taken by Flannery O'kafka (see next page). This image of a mountain rising from the Lysefjord was already somewhat accidental and damaged in that the camera, as occasionally happens, allowed an 'extra' photo to be taken at the edge of the roll of film. Due to this, adhesive blurs the final segment of the picture as you look at it from left to right. In that compromised space we also encounter the hole. The severe and sudden circle that punctures the vertical line that demarcates the clear portion of the photograph from its blurred ghostedge resulted from a processing error made by the photographer when preparing her film for development. She was arrested by the resultant 'broken' image and decided, rather than discard it as ruined, to exhibit it as part of her art practice (conversation with O'kafka; see also McDowell 2016; Almond 2016).

The photograph quite literally exemplifies Graham Harman's reading of Heidegger's broken tool-being. The accidentally punctured image withdraws from the use the photographer had for it, and she in turn, instead of ignoring this rip in the fabric of reality, acknowledges its signal of ontic excess by preserving and displaying the broken photograph. The gap-producing malfunction in turn, for us, invites uncanny recognition of the "erupting infernal universe within" the mountain photographically represented (Bogost 2012, 22). ${ }^{11}$

The hazy segment of the photograph begins just at the place where the picture reveals a hardy tuft of flora growing from the upper rock, a signal that the mountain consists of more than 'inorganic' plate tectonics. The adhesive softens the fjord mountain's harsh edges (more bare and jagged than Scottish mountains tend to be) into 


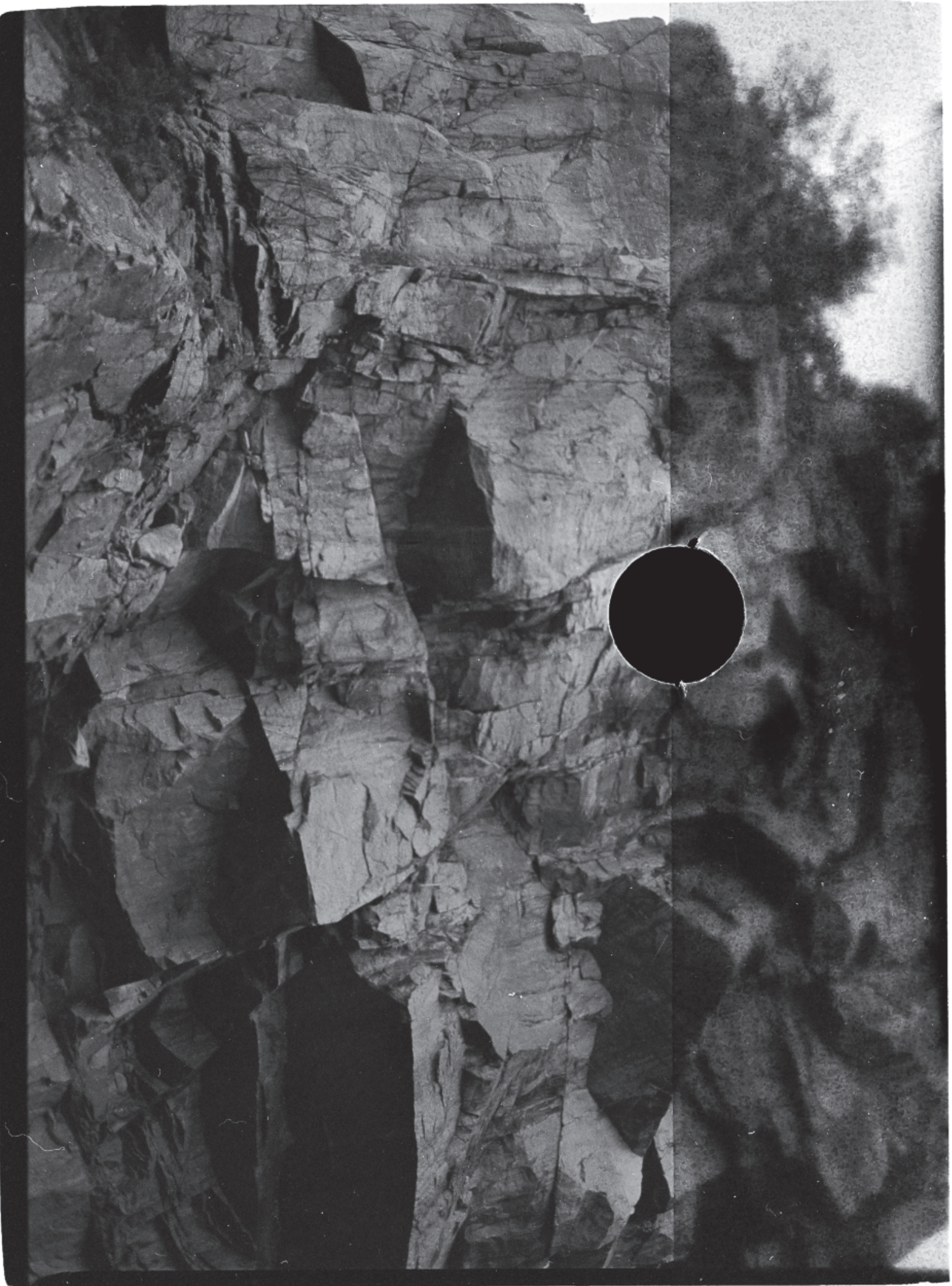


something more ethereal and dreamlike, loosening up the apparent rigidity of its stony ontology. Following the dream logic suggested by this edge, the eye is drawn into the perfect blackness of the hole that straddles the clear and fuzzy segments of the image. We might consider it an invitation into the thought realm of what Morton calls the 'arche-lithic' mind (Morton 2016, $77 \mathrm{ff}$.), which thinks into, rather than denies, the "invisible rift" between being and appearing (ibid., 91, 107).12 It acknowledges and lives with the "haunting gap", the hole, that persists between phenomenon and thing (ibid., 93), between its coruscating surfaces and its dark interior.

This Norwegian mountain, for example, intertwines in certain ways with the tourists on the boat, in other ways with retirees living in the houses on the islands of the fjords, in another way with the icy water that laps at its lower reaches and the icy wind that batters and claws its upper reaches, and in yet another way with the goats we saw nimbly navigating its sheer rock face (even their goaty horns and hooves intertwine one way with the mountain, perhaps clacking and scraping on its rock at a misstep, while their goaty bleats intertwine with the mountain in a different way, through soundwaves reverberating from the rock recesses, hot breath modifying condensation on the rock)... and so on, ad infinitum.

Yet not even the sum of these resplendent interrelationships (were it even calculable) completely captures just what the mountain is. The mountain always has an undepleted reserve of being. Morton's arche-lithic thinking is comfortable (or comfortable being uncomfortable) with this irreducibility. "Arche-lithic mind is immersed in a non-totalizable host of patterns that cannot be bounded in advance: lifeforms, ghosts, phantasms, zombies, visions, tricksters, masks" (ibid., 84).13 And this sense of liminal plenitude is acknowledged "not because things are unreal but because they are real" (ibid., 85-86). The hole in the photograph and its blurred edge have invited us into this arche-lithic thought space.

If the mountain exists in this haunted, riven way, then our thoughts and words about the mountain must follow its lead into the hole. As Haraway observes, it is precisely the "holes in Being" that "generate richer, quirkier, fuller, unfitting ongoing stories" about human-nonhuman entanglement (Haraway 2016, 40). Our stories, about mountains as about all else, must be 'unfitting' because no single narrative or even 'way of life' entirely fits the world, for "reality is too real to be translated without remainder into any sentence, perception, practical action, or anything else" (Harman 2012, 16; cf. Bennett 2010, 122).

Morton also writes of holes. When we tear ourselves away from an anthropocentric outlook and think at an ecological scale, "we discover a hole in our psychological universe" (Morton 2010, 31). The hole is our realisation that there "is no way of measuring anything anymore" due to the "the scope of the [ecological] crisis and the vastness and depth of interconnectedness" (ibid., 31-32). We are truly inside this reality with no ability to take an outside "impartial measurement" (ibid., 31). This "tear in the real" has actually always been with us, if often ignored, and our renewed awareness of it confronts us with the question: will we "paper over the crack" or "go all the way into the hole" (ibid., 31)? Let us at least begin to go all the way into vast and deep ecological interconnectedness and crisis through the specificity of mountain being. We will take the stark dark-room puncture as a portal, a spooky arche-lithic doppelganger of the actual cave entrances in the cliff face visible from the waters of the fjord (see next page), and enter its ontic darkness, even if only by falling.

Indeed, perhaps down instead of up is the direction to go in the effort to deanthropocentrise our view. From my own ex- 


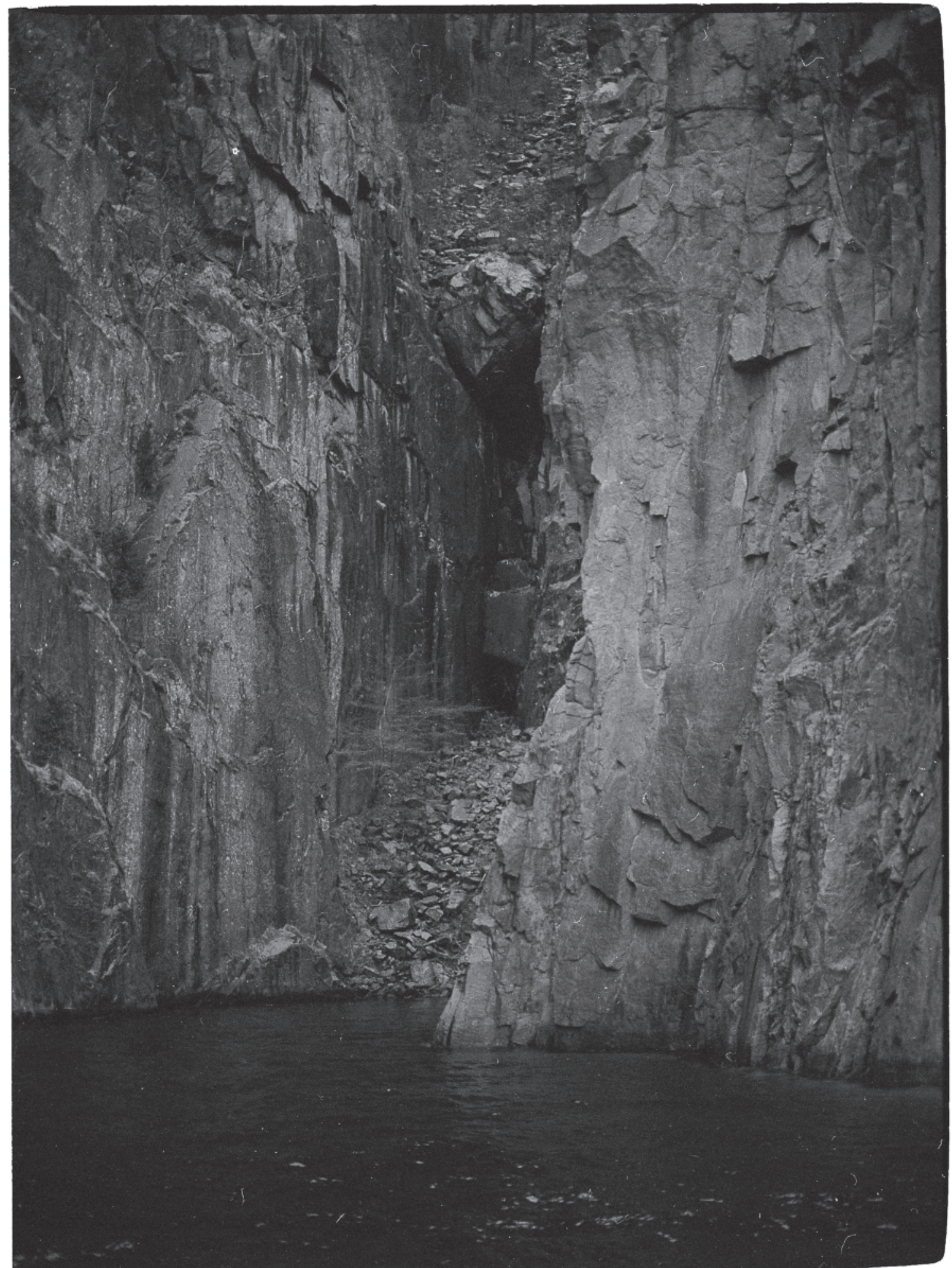


perience with the Scottish Cairngorms, I can confirm Nan Shepherd's observation: "One does not look upwards to spectacular peaks but downwards from the peaks to spectacular chasms" (Shepherd 2011, 2) and thus, especially if those chasms are traversed, one discovers that "a mountain has an inside" (ibid., 16). It was one of the most memorable sights of my life when we pulled off at a lookout point in the Cairngorms National Park and found ourselves not looking up towards peaks (as one does from the road in, say, Glencoe or Skye) but downward into dizzying depths of mountain life, which one cannot observe without walking out to the lookout point - the sunken, sweeping view is invisible from the road. Let us set up another weird echo then between that Scottish geomorphology and this Norwegian one. Though my wife and I craned our necks up toward the mountains rising out of the fjord (and her photos are from this angle), I here suggest - through these strange, affective-contemplative techniques - that those who engage Norwegian mountains also peer (and veer) downward into the vertiginous abysses of their being.

And bottomless they are. To descend into this ontological gorge is to seek knowledge of the mountain, yes, but not closure. "Knowing another is endless", Shepherd wrote,

It is a journey into Being; for as I penetrate more deeply into the mountain's life, I penetrate also into my own. (...) To know Being, this is the final grace accorded from the mountain. (Shepherd 2011, 108)

This is one way of 'thinking like a mountain', adopting not only the long view suggested by Aldo Leopold's influential essay of that title (Leopold 1978, 137-141), but also having our own ontology named by the mountain, as Shepherd's words suggest, even as we imagine we are discovering something of its own dark being. The mountain has something to give us. To receive it, one must go all the way into the hole.

\section{Rotach: Porous Pilgrims AMONG STRANGE STRANGERS}

Inside the ecological hole, we find that we ourselves are also full of holes. Here the human begins to become monstrous like the mountain, for humanity is no longer categorially distinct from ecology or the environment', but instead discovers its capacity for saturation and accretion. Tom Lynch, evoking the mountainous landscape of a very different climate than our arctic one, writes that even though pictorial descriptions of a region can appear to privilege the viewpoint of human sight, the fact is that "the landscape suffuses my body"; in weather, sounds, smells, and so on "the phenomena of this world circulate through me, and I through them. The landscape caresses as I pass through" (Lynch 2008, 10). Anyone who has, for instance, felt their skin, hair, and clothes bejewelled by precipitation whilst walking in mountainous regions - or, as we did on the fjord boat, felt the icy wind thrashing through bundled clothing with a thousand freezing needles - will know of this 'caress' of the landscape. But humans and mountains flow through one another in many other ways as well, such as language.

A sense of land infusing and transecting humans is echoed in O'kafka's artist's statement accompanying her entry into CitizenM Hotel's 2016 exhibition A Private View of Place (a series of photographs that includes an image related to this article). Her series is entitled Rotach: We are Pilgrims and Strangers and explores the northern Scottish landscape's presence in regional language and its travels through human carriers into other locales. The lines of migration are tangled in this case, as we are originally from the United States, now living in Glasgow (Scotland's largest city 
where there is a very small but significant number of Gaelic speakers and schools), and our children are learning the language of highlands and islands they have only ever visited:

We have moved across an ocean and raised children in a big city, speaking an old language. Scottish Gaelic is nearly impossible to separate from the land it comes from. It is spoken in peculiar places where some of the highest hills are black or red, where the traditional songs often speak of loss and displacement. The names of colours are derived from those found in the landscape. The many words for green, blue, and grey are especially fluid and can be used interchangeably when describing the grass, the sea, and the sky.

This work is a travelogue of a Summer in the Highlands and the Isle of Skye, photographing where the language is spoken. Making diptychs with portraits and landscapes, I am seeking to address the cultural disconnect between the mainland-city Gaelic speaker and the original land the language is tied to. This is our story and it is the story of many people leaving or fleeing lands for new lands and learning to speak the languages of those places.

Rotach translates as 'dirt from travelling on body or clothes.' It is a physical manifestation of the landscapes that we carry with us when wandering.

\section{(A Private View of Place 2016)}

However we may describe or depict it, we cannot escape the land's vibrant agency upon us (Bennett 2010). It insinuates itself into our language, thoughts, and feelings and demands that our words, concepts, and affections stretch and proliferate in order to integrate its many-hued repleteness. It makes humans dirt-y. It travels with them. "Place and mind may interpenetrate till the nature of both is altered" (Shepherd 2011, $8)$. Recognition of this more-than-human interpenetration can make us freshly aware, whether at home or abroad, that we are Strangers in a Strange Land, that "buman being is just one way of being in a mesh of strange strangeness - uncanny, open-ended, vast: existence is (ecological) coexistence" (Morton 2011, 165-166). With this sense of the human fully suffused by the nonhuman we may cultivate a tingling receptivity and porosity towards whichever mountains we may climb, view, study, live with, or fight for (see, for example, www.savethefjords.com).

In this porous mode of mountain exploration "one walks the flesh transparent" in Nan Shepherd's memorable phrase (Shepherd 2011, 106). This is not a diminishing of flesh, but its ecological fulfilment. "The body is not made negligible, but paramount. Flesh is not annihilated but fulfilled. One is not bodiless, but essential body" (ibid.). It is a dis/relocating encounter that induces a "deepening into something that resembles trance", until one declares: "I have walked out of the body and into the mountain. I am a manifestation of its total life, as is the starry saxifrage or white-winged ptarmigan" (ibid.; explorers of Norwegian mountains may substitute botanical and ornithological examples of Nordic specificity). In such multi-bodied entanglements "we seep farther and farther into the weird relations between objects" (Bogost 2012, 81) and even begin to fuse with them in "humannonhuman hybrids" (Morton 2016, 145).

As Shepherd also noted: 'The perfect hill companion is the one whose identity is for the time being merged in that of the mountains, as you feel your own to be' (Shepherd 2011, 14). We become Haraway's 'symchthonic ones', co-earthly beings whose 'tentacular' connectivity gives no quarter to human exceptionalism (Haraway 2016). This more-than-human mesh can appear repugnantly monstrous to anthropocentric outlooks that see human being as pristinely distinct from nonhuman 
being. Nevertheless, for those willing to undergo (re)enmeshment, it evokes "monsters in the best sense": ontically betentacled beings that reliably writhe out of exceptionalisms and reductionisms of all sorts and relentlessly wriggle into muddy "muddles" of companionable coexistence (Haraway 2016, 2, 31).

\section{BEARING WitnESS: TransmogRIFIED IN THE TEETH OF THE MOUnTAINS}

This monstrosity in the best sense makes 'point of view' (so important to literature and narrative studies) a shared trope among all kinds of beings. As the human transforms into a thing multiply transected by other things, a plenitude of perspectives is unleashed (cf. Bennett 2010, 116). To round out our meditation, then, let us hear from three voices on this matter: our redoubtable guide, Nan Shepherd; Luce Irigaray, from her engagement with a different strand of the ecosphere; and finally, my own testimony from a few more personal encounters with Scottish mountains.

In a way weirdly resonant with how the disruptive/eruptive hole in O'kafka's photograph elicits deeper, stranger engagement with the mountain, Nan Shepherd makes the odd suggestion that the mountain walker bend over and look between her own legs at an upside down view of the mountains. This rather comic action yields an awesomely de-anthropocentrising vision:

Details are no longer part of a grouping in a picture of which I am the focal point, the focal point is everywhere. Nothing has reference to me, the looker. This is how the earth must see itself. (Shepherd 2011, 11)

Shepherd's experience comports with Luce Irigaray's account of encountering vegetal being. While gazing at a rose, she writes, the 'combination of the sensible qualities of the flower gathers me' and 'I am brought from concentration to contemplation'
(Irigaray and Marder 2016, 47). The human is gathered into the nonhuman by the latter's sensuality (just as the sensible qualities of the fjord mountains gathered Flannery and I and refused to become merely a scrapbooked memory). This yields yet another sweeping inversion of anthropocentrism:

Then man is no longer the one who gathers everything and everyone in a whole, starting from himself and his language: a human is a living being among other living beings, each one remaining faithful to one's roots and natural belonging without mastery over or confusion with others. It is the specificity of each embodiment and its respect by others that secures and maintains the place of every living being. (Irigaray and Marder 2016, 48-49)

Every being ('living' and otherwise, the lithosphere no less than the biosphere) has its respected place, yes, but we must also honour the fact that those ontological places overlap. We occupy one another. We can only see the earth as it sees itself by remembering we are the earth, beings formed of mud and rock and water who never escape those elements but ever return to and merge with them (cf. Cohen 2015 , 20). "Humans do not rise above the world but only burrow ever more deeply into it, digging down toward the heart of things by fusing with them" (Harman 2010, 134).

Down inside this hole, no longer only human, we "see ourselves as objects traversed - translated by others" (Morton $2011,171)$. And not only translated but "penetrated by other entities" (Morton $2016,125)$. Here the mountain transmogrifies us into something anthropo-lithic, a were-mountain comprised not only of our original fleshy skin but now also of steep rocky walls, moss, streams, scrub, wind, rain, ice - the gorge-life and the peak-life. In antipathy to a disembodied 'panopticon' view of the mountains, we have become monstrously entangled: 
There is only a continual embedding of my flesh with the flesh of the world, a continual interfusion of self and environment through the semi-permeable membranes of my skin, senses, and imagination. (Lynch 2008, 11)

And so we feel in our very flesh that mountains are monstrous, not only in their gigantism but in their hybridity. We (re)discover ourselves in the teeth of their entanglements, and in their chewing up of the human into the nonhuman. When we walk out of the body and into the mountain, as Shepherd wrote, the mountains return us to our bodies multiplied and diffracted, reminding us we have always been made up of others and that those others are made up of us as well (cf. Bennett 2010, ix).

I too have been sucked into the vortices of human-nonhuman enmeshment on mountainsides and thus will also "try to bear witness to the vital materialities that flow through and around us" (Bennett $2010, x)$. In one instance, as my friend Jonathan Queen sat at a lookout point and painted the Three Sisters of Glencoe (a trio of mountains mentioned at the opening of this essay), I rambled down into a small riverbed somewhere below the gathered sightseers at the roadside (cf. Smith 2015). Eventually, I looked back in that direction and couldn't see my fellow humans anymore. There are few intervening trees in these types of areas in Scotland, but the incline one descends can fairly quickly cut off the view of your starting point. I was immediately struck by how different it was down here in the midst of the landscape rather than over against it at the place above. The quality of sound was completely altered. The wind and running water were discernible and an almost palpable quiet blanketed the space. I found that my eyes were drawn away from the peaks down toward individual rocks, plants, and insects. The Three Sisters towered over me as I played in the folds of their skirts. I was swallowed alive by mountains.
On the same occasion that I pulled my car off the road and looked down into one of the gorges of the Cairngorms, I also climbed a ways down into those gorge-ous depths by descending the narrow, winding paths that the sheep use in those parts. For some reason, I was struck with the impulse to lie down in the firm dirt there, the path barely wide enough for the width of my shoulders. When I did so I found my body was prone in a sudden hush below the thrashing of the wind through the rank grass and heather just above this slightly sunken trail. The human was for a moment submerged into the mountain's life. I could not rely on my sight and even my hearing took in only the comparative silence. I could only feel the mountain pressing into my back and enveloping me in its turf. Shortly after this, I left these sheep tracks and climbed back upward through the mountainside's dense, scrubby, low growth. For my trespassing, I was startled by a surprisingly large and speckled grouse suddenly and noisily detaching its body from its camouflaged place in the heather. I recoiled as it charged along the ground before taking violent flight. Then I laughed at myself for my fright and for the joy of the decentring encounter. I had once again tumbled down the hole into mountain being.

"To think like a mountain does not mean to scale a rocky slope in search of a god's-eye-view, as if the world could be glimpsed from outside" (Cohen 2015, 21). Indeed, again and again the mountain pulls our thinking inside. Here be monsters. Uncanny contact with strange strangers. Intimacy with an alien presence. The monstrosity is not only in the topographical profundity of the great tectonic uplift upon which these comminglings take place, but in the mixtures, encounters, and inversions the mountain hosts on its hide. 


\section{ENvoi: Following THE SCENT}

I agree with Bennett that there is "public value in following the scent of a nonhuman, thingly power", in the sense of "to follow' that Derrida developed in his meditation on animals and being: "to be (anything, anyone) is always to be following (something, someone), always to be in response to [a] call from something, however nonhuman it may be" (Bennett 2010, xiii, referring to Derrida 2002). I have heard that call from the Norwegian mountains and have attempted to respond to it by following the scent of their ontologies as they recede into their dark interiors.

In this faltering and largely indirect assay, we have tried to fall down into the ontic hole the broken photograph opened to us. It is hoped that our onto-poetical peregrinations, if more than a little fanciful and furtive, have nevertheless suggested how we might enter "nonarrogant collaboration with all those in the muddle" and that, if only we will humbly embrace the dis/relocation the mountains offer us, "we can join in the metabolic transformations between and among rocks and critters for living and dying well" (Haraway 2016, 56). Such nonhuman-human collaborations and transformations are, to my mind, the lifeblood of ecological thinking and living, of re/cognising the scope of interconnectedness, and of treading the earth in step with that eerie awareness - walking the flesh transparent, out of our bodies and into the mountain and back into our bodies transfigured, as human-shaped textures of the mountain's skin.

Of what use are such monsters? None at all. For though "they demonstrate and perform the material meaningfulness of earth processes and critters" to those prepared to learn, "they belong to no one; they writhe and luxuriate in manifold forms and manifold names in all the airs, waters, and places of earth. They make and unmake; they are made and unmade. They are who are" (Haraway 2016, 2).

\section{NOTER}

1. For O'kafka's artist's statement and CV, see www.flanneryokafka.com. For featured work, see: www.wild-fires.org/\#/flannery-okafka/. For the paper I presented at this conference, cf. Petersen 2016.

2. Bennett argues that to anthropomorphise is "to relax into resemblances discerned across ontological divides", which, "oddly enough, works against anthropocentrism: a chord is stuck between person and thing, and I am no longer above or outside a nonuman 'environment"' (Bennett 2010, 119120; cf. Bogost 2012, 65).

3 . The geographers David Mark and Barry Smith stumble into the suggestion of a different sort of gigantesque anthropomorphic image when they argue that mountains are 'attached' objects, the kind "which project out of, or form parts of the surface layers of, larger objects; for example, the nose on your face, the handle on your door" (Smith and Mark 2003, 423). That a mountain resembles a face is a gigantic notion. That a mountain might be likened to merely the nose on the face of a much larger land mass multiplies this sense of gigantism by many degrees!

4. The use of 'we' and 'our' in the remainder of this article is as provisional as the rest of its approach. It merely signals an inclusive invitation to think with this article's attempt to think with the mountains. It is for the reader to 'try on' as she will and discard as she pleases.

5. This marks another distinction between this article and the story to which its title alludes. In $A t$ the Mountains of Madness, Lovecraft's monsters are discovered in, beyond, and behind the wall of mountains at which the explorers arrive. In this article, the mountains themselves are the monsters the other/this-worldly aliens with which we have to do. Furthermore, as in other Lovecraft stories, e.g. 'The Dunwich Horror' (1929) and 'The Shadow over Innsmouth' (1936), human being, through its contact with monstrous mountains, is here transfigured into an ontic shape more monstrous than anthropocentrism allows.

6. I am not convinced by Smith's and Mark's contention that mountains (and landforms generally) exist "but their ontological status is of a secondary sort", which is not to be ranked "with the very joints of reality" (Smith and Mark 2003, 425). This is to 'solve' the mountain's monstrous liminality by removing it from the real, or at least from primary reality, the really real. This seems to affirm that anything we can't account for by crisp and unshifting boundaries is, at best, only tangentially real. Cf. Morton's (2016) argument that such 
ontological shifting and shimmering is precisely the mark of the real.

7. Smith and Mark contend that, considered at a planetary scale, mountains are mere bumps, "variations in the geoid", discernible only to creatures of our (comparatively tiny) size (Smith and Mark $2003,420)$

8. Both Bogost and Morton build on Harman's version of $\mathrm{OOO}$, which consists of a novel analysis of Heidegger's 'tool-being'. Harman takes Heidegger's recognition that a malfunctioning tool signals to us that it exists beyond our uses for it, and radicalises its scope, applying this 'broken tool' status to every object whatsoever as Heidegger's central insight about ontology. Every object breaks away from its 'use' by other objects and withdraws into its dark interior. This take on Heidegger is outlined and reiterated in many of Harman's books: e.g. Harman 2002; 2010; 2012. For a clear summary of Harman's OOO, see Bogost 2012.

9. Cohen himself has certainly moved in this direction with his later writings on ecology, e.g. Cohen 2015.

10. Hence, the venerable and widespread tradition of looking to mountains as axes mundi (cf. Della Dora 2016).

11. Harman notes that there are what he calls 'productionists' as well as reductionists, 'philosophers who find new gaps in the world where there were formerly none', and that 'Lovecraft is clearly a productionist author' (Harman 2012, 3). In this sense, at least, our meditation here is 'Lovecraftian'. For the counter-Lovecraftian view of Haraway's 'Chthulucene' approach (note the spelling), see Haraway 2016, 101, 174.

12. Morton derives his term from Jacques Derrida's concept of the spectral, shimmering archewriting that haunts language (Morton 2016, 80). 13. As one might apprehend from this list, Morton acknowledges that crucial elements of his ecological vision can be found in the thought and life of 'first peoples' as much as in recent developments in object philosophy (Morton 2016, 80). Bennett acknowledges the affinities her work may have with indigenous worldviews and other "nonmodern (and often discredited) modes of thought" (Bennett 2010, xviii). Haraway (2016) for her part positively fosters such affinities.

\section{REFERENCES}

- A Private View of Place. 2016. [Exhibition]. CitizenM Bankside Hotel, London. May - June.

- Almond, K. 2016. A hole punched through history. CNN. [Online]. April 7. [Accessed March 26 2017]. Available from:

http://edition.cnn.com/2016/04/07/politics/g allery/tbt-hole-punched-history/index.html.

- Bennett, J. 2010. Vibrant Matter: A Political Ecology of Things. Durham: Duke University Press. - Bogost, I. 2012. Alien Phenomenology, or What It's Like to Be a Thing. Minneapolis: University of Minnesota Press.

. Cohen, J. 1996. Monster Culture: Seven Theses. In: Cohen, J. ed. Monster Theory: Reading Culture. Minneapolis: University of Minnesota Press, 3-25.

- Cohen, J. 2015. Stone: An Ecology of the Inhuman. Minneapolis: University of Minnesota Press. - Della Dora, V. 2016. Mountain: Nature and Culture. London: Reaktion Books Ltd.

- Derrida, J. 2002. The Animal That Therefore I Am (More to Follow). Critical Inquiry. 28(2), 369-418.

. Haraway, D. 2016. Staying with the Trouble: Making Kin in the Chthulucene. Durham: Duke University Press.

- Harman, G. 2002. Tool-Being: Heidegger and the Metaphysics of Objects. Chicago: Open Court.

- Harman, G. 2010. Towards Speculative Realism:

Essays and Lectures. Winchester: Zero Books.

- Harman, G. 2012. Weird Realism: Lovecraft and

Philosophy. Winchester: Zero Books.

- Irigaray, L. and Marder, M. 2016. Through Vegetal Being: Two Philosophical Perspectives. New York: Columbia University Press.

- Lynch, T. 2008. Xerophilia: Ecocritical Explorations in Southwestern Literature. Lubbock: Texas Tech University Press.

- Leopold, A. 1978. A Sand County Almanac.

New York: Ballantine Books.

- McDowell, B. 2016. Ground: A Reprise of Photographs from the Farm Security Administration.

Daylight Books.

- Morton, T. 2011. Here Comes Everything: The Promise of Object-Oriented Ontology. Qui Parle. 19(2), 163-190.

- Morton, T. 2016. Dark Ecology: For a Logic of Future Coexistence. New York: Columbia University Press.

- Petersen, D. 2016. Cowboys and Indians... and Cthulhu! Ecomonstrous Encounters in the Fiction of Cormac McCarthy and R. A. Lafferty. Promises of Monsters Conference, April 28-29, University of Stavanger, Stavanger. 
. Price, M. 2015. Mountains: A Very Short Introduction. Oxford: Oxford University Press.

- Shepherd, N. 2011. The Living Mountain. Edinburgh: Canongate Books.

. Smith, R. 2015. Jonathan Queen Paints with Toys. Cincinnati Magazine. [Online]. August. [Accessed 22 September 2017]. Available at: http://www.cincinnatimagazine.com/artsmindsblog/jonathan-queen-paints-with-toys/. . Smith, B. and Mark, D. 2003. Do mountains exist? Towards an ontology of landforms. Environment and Planning B: Planning and Design. 30(3), 411-327. 